\title{
Statistical Analysis For Establishing The Relation Of Decadal Rainfall Data And Variation In Ground Water Levels: A Case Study Of PTW1 Watershed, Buldhana District Of Maharashtra State
}

\author{
V. M. Rokade ${ }^{1}$ and S. S. Naitam ${ }^{2}$ \\ ${ }^{1}$ School of Environmental and Earth Sciences, KBC North Maharashtra University, Jalgaon (MS) - 425001 \\ ${ }^{2}$ Directorate of Mining and Geology, Govt. of Maharashtra, Bhandara (MS) - 441904 \\ E-mail:drvmrokade@gmail.com, Mobile:09420568050
}

\begin{abstract}
Groundwater is a dynamic natural resource, from place to place it varies quantitatively and qualitatively. Potential of the groundwater is mainly depends upon rainfall received, lithological setup, geomorphic landforms, depth of weathering and soil, drainage network and hydrogeological properties of the rocks of an area. Increasing demand of the groundwater needs to evaluate the existing trend and availability of groundwater in time and space for proper planning and sustainable development in the area. Past decadal groundwater levels and rainfall details provides an important facts and figures for studying long term changes in groundwater system of an area. For such study, in present investigations decadal (2002 - 2012) trend of premonsoon and post-monsoon groundwater levels and rainfall details of PTW -1 watershed of Buldhana district has been statistically analyzed. Results of the present research shows positive correlation indicating declining trend in pre-monsoon period and rising trend of groundwater levels in post-monsoon time. Such historical water level trend analysis is useful for judicious future planning of groundwater utilization.
\end{abstract}

Keywords- Groundwater; static water level; rainfall data; Groundwater level fluctuation; Statistical analysis

\section{INTRODUCTION}

Water is a very essential natural resource for survival of life on earth. Nowadays, whole world facing a major problem of water scarcity and is need to overcome it by diverting surface runoff to augment groundwater resources. When the natural recharge rate cannot meet the demand for water, the balance is disturbed and hence calls for artificial recharge on a country wise basis (Rokade, 2004). The artificial recharge projects are site specific and even the replication of the techniques from similar areas are to be based on the local topographical, hydrogeological, landuse/landcover and socioeconomic environment of the area.

Developments in new technologies such as geostatistics, geographic information systems, and remote sensing provide new approaches to meet the demand of resource-related modeling (Mermut and Eswaran 2001; Salehi et al. 2003; Yasrebi et al. 2008). In present research paper an attempt has been made to utilize statistical methods for getting the relation of rainfall and ground water levels. The overall general goal of this paper is to study the pattern of a spatial distribution of groundwater levels and rainfall pattern of the study area.

\section{STUDY AREA}

Study area is located in the Northern west part of the Buldhana district of Maharashtra state. It lies between Longitude $75^{\circ} 55^{\prime} 00^{\prime}$ and $76^{\circ} 15^{\prime} 00^{\prime} \mathrm{E}$ and Latitudes $20^{\circ} 41^{\prime} 00^{\prime \prime}$ And $20^{\circ} 59^{\prime} 00^{\prime \prime} \mathrm{N}$, mapped by Survey of India in toposheet nos. 55D/1 and 55D/2 on 1:50,000 scale and cover 193.52 sq.km area (Fig. 1). PTW - 1 watershed is forming a part of Vyaghra SubCatchment, Purna Catchment, Tapti River Basin and Arabian Sea Water Resource Region (AIS \& LUS, 1988). As per All India Soil Survey and Land Use Survey (AIS \& LUS) codification system the studied area has been coded as 5C4B6 (5-Water Resource Region i.e. Arabian Sea, C-River Basin i.e. Tapti, 4Catchment i.e. Purna, B-Sub-Catchment i.e. Vyaghra and 6-Watershed i.e. PTW - 1).

The climate of the area is dry and hot except during the monsoon period and the average annual rainfall of the area is $712.96 \mathrm{~mm}$. About $99 \%$ of the annual rainfall is received during the southwest monsoon season during the months of June to September. Average temperature in the area varies from $15{ }^{\circ} \mathrm{C}$ to $47^{\circ} \mathrm{C}$ and the air is dry except during monsoon period. Agriculture is the main practice for survival of human beings, prominent crops harvesting in the area are Cotton, Jowar, Bajara, Maize and Grains. 


\section{DATA USED AND METHODOLOGY}

The database for this study area is derived from the periodic and routine monitoring of depth to water level of Groundwater Survey and Development Agency, Buldhana through the observation wells and relation of water level fluctuation is studied by drawing regression line using least square technique.

Fig. 1: Location map of the area.

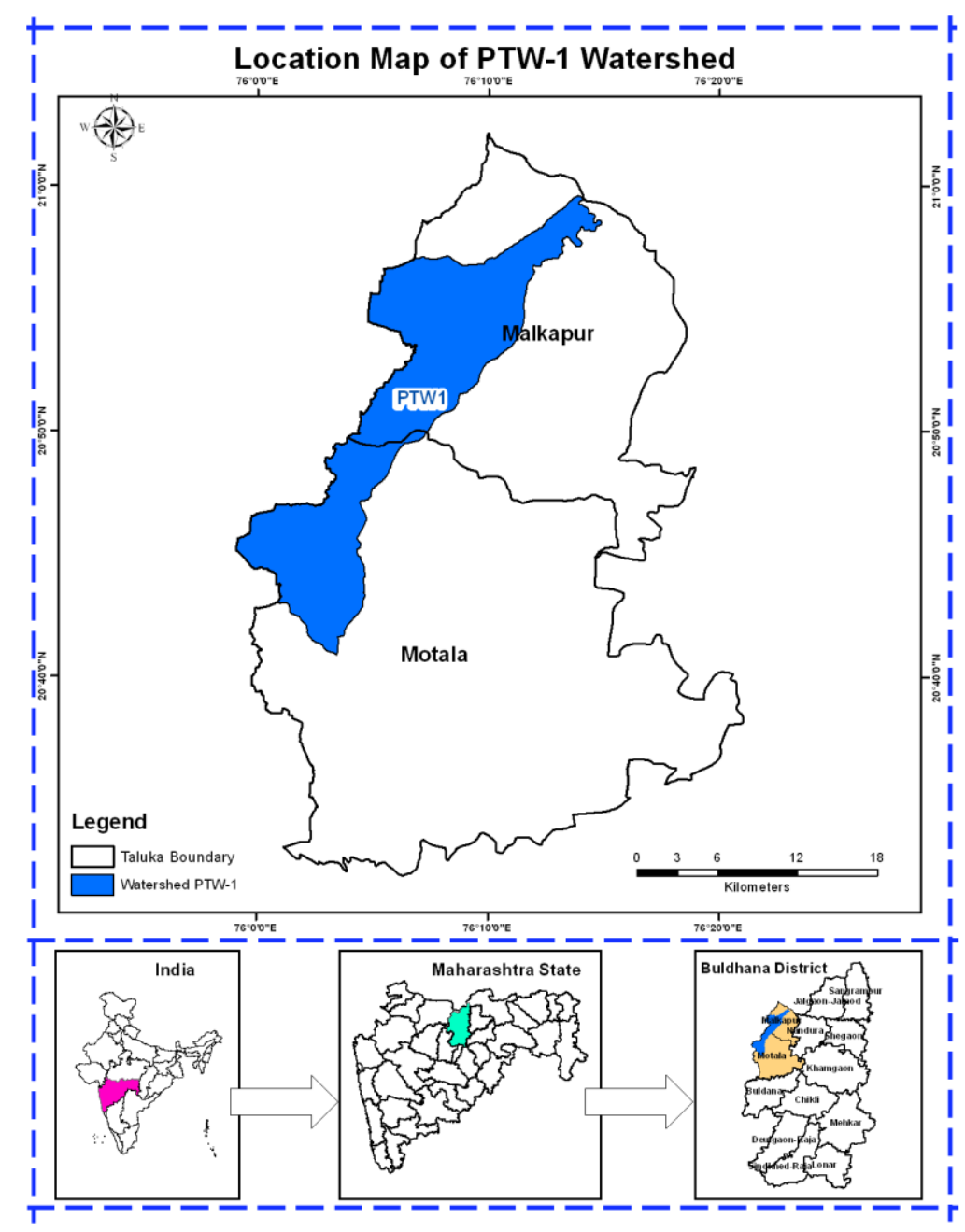

Fig. 2: Map depicting geological setup of the area.

located at Urha and Pimpalgaon Devi villages of Motala taluka and Hingana Kazi village of Malkapur taluka distributed in the study area. Geodatabase on geology, geomorphology, depth of weathering etc. is collected during field visits. Information on drainage

characteristics are studied from Survey of India (SOI) toposheets.

The depth of the aquifer zones are lying generally within the range of $30-70 \mathrm{~m}$ bgl. The database on rainfall for the time span of 2002- 2012 (10 years) is considered and pre- and post-monsoon depth to water levels for these consecutive years are used in the statistical analysis. Trend of the rainfall

\section{RESULTS AND DISCUSSION}

\section{Geological Setup of the Area}

On the basis of well $\log$ observations, field work and existing District Resource Map of Buldhana district (1: 2,50000 scale) published by Geological Survey of India, the area have been mapped (Fig. 2). Alluvium and basaltic flows of Deccan Trap constitutes geology of the study area (GSI, 2000). Quaternary alluvium mainly consists of clay and sand deposited in the central part of the watershed and north of the Malkapur town. Entire thickness of the alluvium is reported from the range of $1.5-3.0 \mathrm{~m}$. The alluvium is underlined by Upper Cretaceous to Palaeogene Deccan volcanic flows. Deccan trap is represented distinctly at different places at Wadgaon, 
International Journal of Research in Advent Technology, Vol.7, No.3, March 2019 E-ISSN: 2321-9637

\section{Available online at www.ijrat.org}

Pimpalgaon Devi, Mahalungi, Lapali Sindhkhed and Ridhora Khurd of Motala taluka. Greenish highly weathered vesicular basalt, Greyish moderately weathered jointed massive basalt, highly weathered greenish vesicular basaltic flows with thickness of $7.00 \mathrm{~m}$ to $10.00 \mathrm{~m}$ have been observed at Gugali, Kolhi Golar, Dahigaon of Motala taluka and Wadaji Malegaon and Harankhed of Malkapur taluka. Two aa flows and 8 compound pahoehoe flows of Ajanta formation are reported at Jambhukdabha, Gaulkhed, Khamkhed and Hingana Kazi of Malkapur taluka in the study area (GSI, 2000). Major NE-SW, N-S, NNW-SSE and NW-SE trending lineaments, fractures, vertical and columnar joints in basalts behaves a good aquifer.

\section{Geomorphology of the Area}

Geomorphic landforms control the groundwater potential of the area. On the basis of SOI Toposheets, field visits and well data and by considering the relief, slope, depth and type of weathered material geomorphologically area is classified as Highly Dissected Plateau (HDP), Moderately Dissected Plateau (MDP), and Alluvial Plain (Fig. 3). Maximum area of the sub-watershed is characterized by upper plateau having poor to moderate groundwater prospecting. South eastern areas of the watershed exhibiting highly dissected plateau (HDP) Total 10 villages comes in this zone i.e. Wadgaon, Pimpalgaon Devi, Mahalungi, Sonbarad, Lapali, Sindhkhed, Liha Bk, Ridhora Khurd, Gugali and Kolhi Galuka of Motala taluka. Moderately dissected plateau (MDP) is shown by villages like Urha, Dahigaon of Motala taluka and Chinchkhed, Malegaon, Wadaji, Harankhed, Aland of Malkapur taluka.An eroded alluvial plain is observed in Northern areas of the watershed in village Jambhuldabha, Gaulkhed, Khamkhed, Hingana Kazi, Jalalabad, Wajirabad, Bhalegaon and Nimbhari of Malkapur taluka. In hydrogeological perspective, ground water in Deccan Trap Basalt occurs mostly in the upper weathered and fractured parts. At places potential zones are encountered at deeper levels in the form of fractures and inter-flow zones. The discharge from these wells varied from 0.14 to 29.16 litres per second (lps) and Static water levels are in the range of 5.20 to $140.00 \mathrm{~m}$ bgl (CGWB, 2009).

\section{Hydrogeological Setup of the Area}

From the hydrogeological investigations through well inventory and water level monitoring it is noted that Deccan trap lava flow and Purna alluvium are key water bearing lithounits in the watershed. Major part of the study area is covered by basaltic lava flows forming an important water bearing formation in the area. The disposition of vesicular unit and massive unit of different lava flows has given rise to multi layered aquifer system. The water bearing capacity of vesicular Basalt largely depends upon size and shape of vesicles, density of vesicles and the degree of inter connection of vesicles. In s tudy a rea, ground water occurs both in vesicular and massive Basalt as well as inter flow zones in weathered mantle, fractured zones. In general ground water occurs under water table conditions in shallow aquifer and semi-confined to confined conditions in deeper aquifer. The unconfined aquifer is developed due to the weathering and jointing of upper flow in Basalt down to depth of 15-20 m bgl.

In Alluvial deposits, inter pore spaces in sand and gravel renders them a high degree of porosity and permeability to make them a good ground water reservoir. However lithological variation results in variable water yielding capacity depending upon the sand-clay ratio. In Alluvium g r o u n d w a t e r generally occurs in confined to semi-confined conditions in the depth range of 11-40 m bgl. Southern area of the watershed is not recommended for groundwater development low groundwater potential.

As per CGWB report, in Alluvium the transmissivity ranges from 0.89 to $1575.96 \mathrm{~m}^{2} /$ day and the storativity ranges from $1.09 \times 10^{-3}$ to $3.00 \mathrm{x}$ $10^{-6}$. The transmissivity in Basalt ranges from 8.35 to $395.85 \mathrm{~m}^{2} /$ day and the storativity varies between $8 \mathrm{x}$ $10^{-8}$ and $4.2 \times 10^{-2}$ (CGWB, 2009).

Slope

Slope has a dominant influence on the contribution of rainfall to stream flow and to the groundwater reservoir. In as much as it controls the duration of overland flow, infiltration and subsurface flow. The slope conditions also control the depth to the water table, pattern of land use/land cover and feasibility of geotechnical constructions for storage and artificial recharge. In the study area, the average height of the plateau is $345 \mathrm{~m}$ and height of the highest peak is $360 \mathrm{~m}$ at Sonbarad village of Motala taluaka. The major part of the area is nearly level slopes $(0-1 \%)$ accounting $89.2 \%$ of the total area of the watershed and occupies the central and northeastern part of the watershed. The foot slopes of the uplands and valley plains in the undulating terrain are having very gentle slopes $(1-3 \%)$ and this class accounts for $5.8 \%$ of the area covering Jambhuldabha, Gaulkhed, Khamkhed, Hingana Kazi, Jalalabad, Wajirabad, Bhalegaon and Nimbhari villages of Malkapur taluka. Gentle slopes $(3-5 \%)$ coincide with undulating terrain and intermittent valley zones, occupying $1.32 \%$ area of the watershed. The moderate slope areas $(5-10 \%)$ are in association with pediments and occupies the northern, north-western, western and south-eastern part of the watershed with an area of about $2.02 \%$ covering Urha, Dahigaon of Motala taluka and Chinchkhed, Malegaon, Wadaji, Harankhed, Aland villages of Malkapur taluka. The 


\section{Available online at $w w w . i j r a t . o r g$}

strong slopes (10-15\%) occupying in the southern and south-eastern parts of the area in association with foot slopes of the hills with an area of about $0.77 \%$. Steep slope gradients (15-30\%) are characterized with mounds in the southern part of the watershed with an
Drainage pattern in the study area is mainly observed as dendritic drainage pattern and small patches of annular drainage pattern at few places (Fig. 3). Dendritic drainage pattern is associated with areas having homogeneous lithology and very gentle and/or

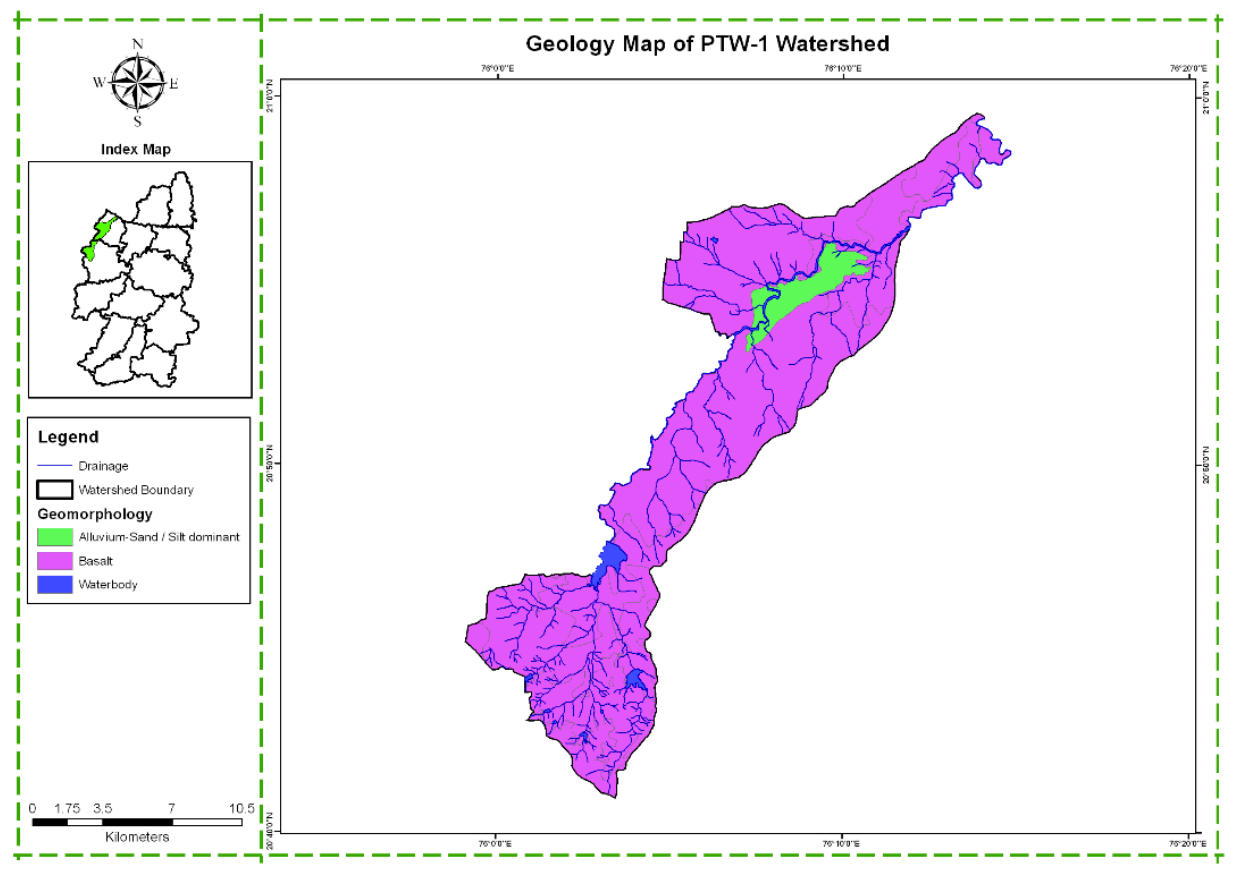

Fig. 2: Map depicting geological setup of the area.

area of about $0.48 \%$ of the area. The very steep slopes (> 30\%) are in association with piedmont slope and plateau with an area of about $0.41 \%$ of area villages are Wadgaon, Pimpalgaon Devi, Mahalungi, Sonbarad, Lapali, Sindhkhed, Liha Bk, Ridhora Khurd, Gugali and Kolhi Galuka of Motala taluka.

\section{Depth of Weathering}

Examination of sections of dug wells observed in the field and litholog data collected from Groundwater Survey and Development Agency (GSDA, 2012) have been used to access the depth of weathering. Degree of weathering and topographic setting also plays a major role in respect of productivity. In Basalt, ground water occurs both in Vesicular and Massive Basalt as well as inter flow zones in weathered mantle, fractured zones. In general ground water occurs under water table conditions in shallow aquifer and semiconfined to confined conditions in deeper aquifer. The unconfined aquifer is developed due to the weathering and jointing of upper flow in Basalt down to depth of $15-20 \mathrm{~m} \mathrm{bgl}$ (GSDA, 2012). The depth of weathering in the watershed varies from place to place.

\section{Drainage Network}

The watershed PTW 1 is drained by the major river Wyaghra and its tributary. Wyaghra River is flowing from southwest to northeast direction. flat, rolling topographic surface with extremely low relief and annular drainage pattern is shown by small hillocks/mounds present in the area. PTW - 1 subwatershed is having basin length of $350.43 \mathrm{~km}$ and total area of $217.46 \mathrm{~km}^{2}$. Drainage area gives amount of water available for recharge in the area. Shape of the area is elongated and dendritic which indicated that less structural control and homogeneous lithology. In study area, the highest peak is having elevation of $360 \mathrm{~m}$ and lowest of $280 \mathrm{~m}$ elevation. The order of the sub-watershed is 4 and maximum stream length in the area is of $17.594 \mathrm{~km}$. Average length of $1^{\text {st }}$ order stream is $0.55 \mathrm{~km}, 2^{\text {nd }}$ order is 1.13 $\mathrm{km}, 3^{\text {rd }}$ order is $1.96 \mathrm{~km}$ and $4^{\text {th }}$ order is of $8.21 \mathrm{~km}$. Stream frequency of the sub-watershed is 2.58 . The higher the stream frequency, the greater is the surface runoff. Drainage density of the study area is 2.23 . Low drainage density is indicative of the presence of highly permeable rocks and high drainage density is characterized by mounds and/or impermeable areas. Average Bifurcation ratio for study area is 3.47 reflecting moderate sediment yield. Relief ratio of the sub-watershed is 4.65 indicating of low intensity of erosion. An elongation ratio of the area is 0.5998 indicating moderate relief with varied geological features. The circulatory ratio of the area is 0.602 indicating sudden discharge of the runoff. For study purpose Watershed PTW 1 is divided into 5 miniwatersheds considering topography, slope variation and drainage density. Mini-watersheds 1 to 4 are characterized by runoff zone and Mini-watershed 5 


\section{Available online at www.ijrat.org}

and 6 are portraying flat topography with weathered depth to water level has been observed during pre-

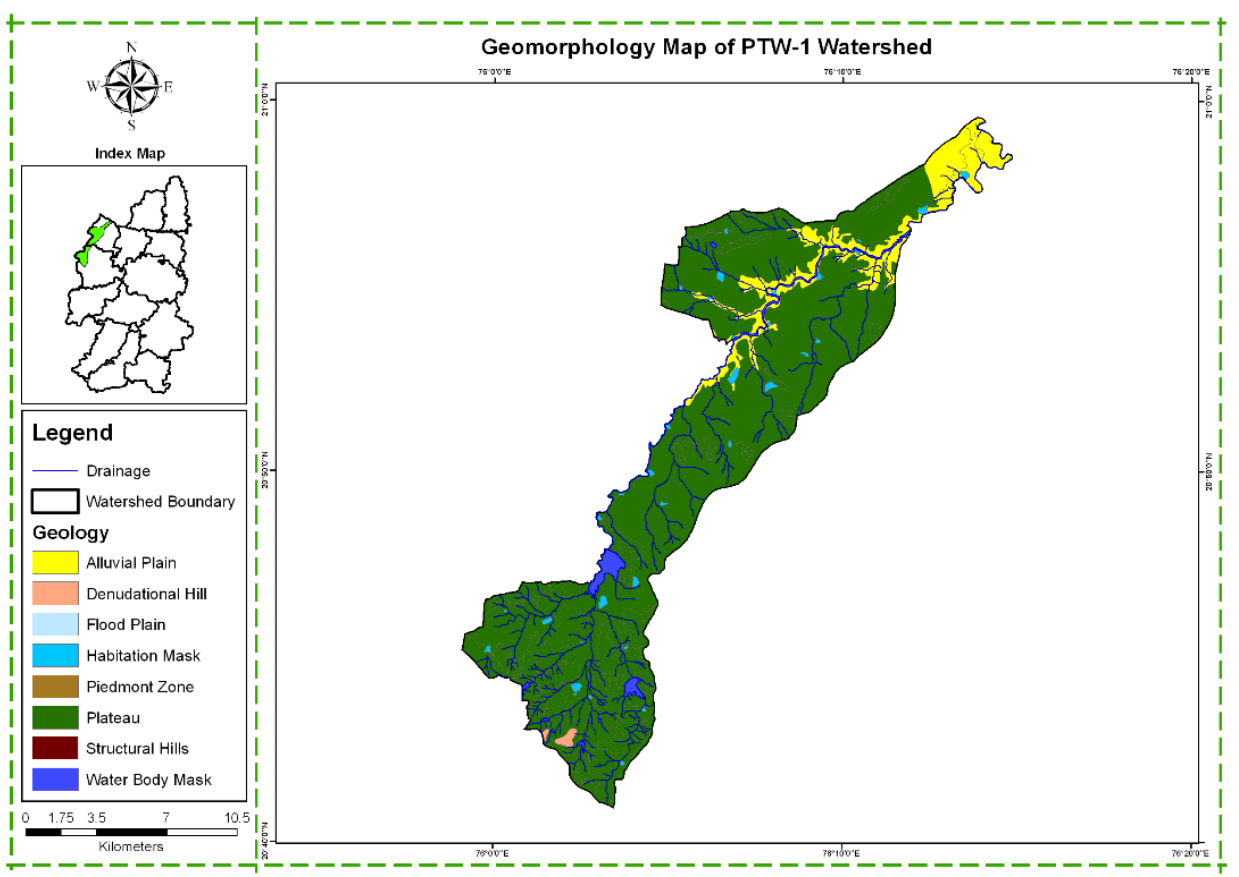

Fig. 3: Map showing different geomorphic landforms in the area.

formations describing the scope for recharge.

\section{Rainfall Data Analysis}

Rainfall recorded for the period of 20022012 (10 years) at Motala and Malkapur rain gauging stations located and analyzed the trend and pattern of the rainfall. Decadal rainfall data analyses indicates that the studied watershed received maximum rainfall of $1000 \mathrm{~mm}$ in the year 2002 and contrary received a minimum rainfall of $401.8 \mathrm{~mm}$ in the year 2005. The annual rainfall over the watershed ranges from 401 $\mathrm{mm}$ to $1000 \mathrm{~mm}$.

\section{Water Level Fluctuation}

The depth to water level recorded by GSDA during the year 2002 to 2012 is considered for the analysis of spatial and temporal trend of water level. In studied watershed water levels are recorded twice a year (May - Pre-monsoon and October - Post-

monsoon). Pre-monsoon and Post-monsoon water levels are monitored at observation wells located at Hingana Kazi, Pimpalgaon Devi and Urha villages and trend of water levels for Pre-monsoon and Postmonsoon period for last ten years (2002-2012) have been computed. Analysis of trend indicates that during post monsoon period, rise in water level has been recorded at all three stations. Shallow water levels within $10 \mathrm{~m} \mathrm{bgl}$ occupy in south, central and northeastern part of the watershed. Water levels between 10 and $20 \mathrm{~m} \mathrm{bgl}$ are observed in north western alluvial areas of Malkapur taluka. Lowering monsoon. Shallow water levels, within $10 \mathrm{~m} \mathrm{bgl}$ are seen in major part of the Motala taluka. Water levels of $10-20 \mathrm{~m} \mathrm{bgl}$ are observed in major northern Alluvial part of the watershed. Deeper water levels of more than $20 \mathrm{~m} \mathrm{bgl}$ are observed in the northwestern part of the Malkapur taluka. 


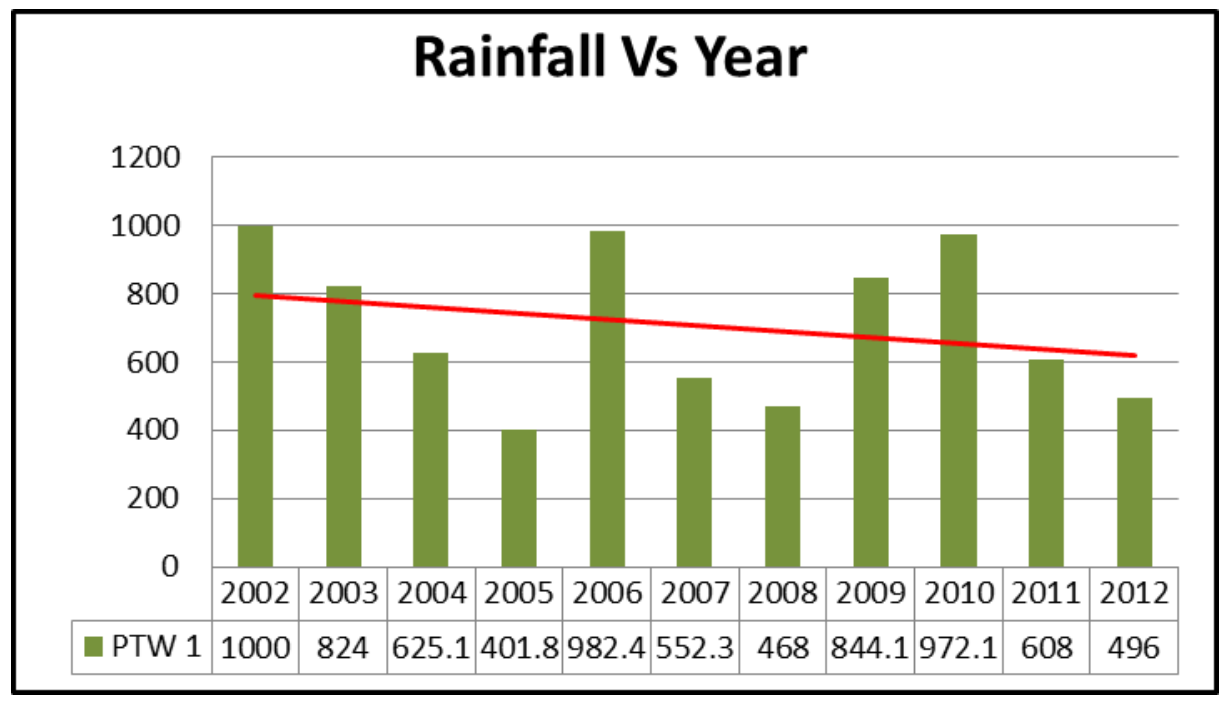

Fig. 4: Decadal rainfall analysis in the area.

\section{CONCLUSION:}

Most of the trend of the groundwater level indicated a strong spatial dependency on the rainfall. Varied hydrogeological behavior of Deccan Basalt is deciphering in the area. Vesicular and massive unit of lava flows shows multilayered aquifer system. Highly porous and permeable alluvium is the prominent source of groundwater. Groundwater level fluctuation in alluvium area is less than that of the Deccan basalt.

\section{REFERENCES}

[1] AIS \& LUS (1988) Watershed Atlas of India, All India Soil and Land Use Survey, New Delhi.

[2] CGWB (2009) Ground Water Information Brochure of Jalgaon District Maharashtra, Published by Central Ground Water Board, Ministry of Water Resources, Government of India.

[3] GSI (2000) Buldhana District Resource Map published by Geological Survey of India.

[4] GSDA (2012) Old Dug Well and Bore Well details for accessing Depth of Weathering and Depth to water Table (Noted from registers).

[5] Mermut, A. R., and Eswaran, H. (2001). Some major developments in soil science since the mid-1960s. Geoderma, 100, 403-426.

[6] Rokade, V. M., Kundal P. and Joshi, A. K. (2004). Water Resources Development action plan for Sasti watershed, Chandrapur district, Maharashtra using Remote Sensing and Geographic Information System, Journal of the Indian Society of Remote Sensing, Vol. 32, No. 4, 2004, pp. 363-372.

[7] Salehi, M. H., Eghbal, M. K., and Khademi, H. (2003). Comparison of soil variability in a detailed and a reconnaissance soil map in central Iran. Geoderma, 111, 45-56.

[8] Yasrebi, J., Saffari, M., Fathi, H., Emadi, M., Karimian, N. A. and Baghernejad, M. (2008). Spatial prediction of surface soil properties using terrain and remote sensing data. Journal Applied Science, 8(6), 1000-1006. 


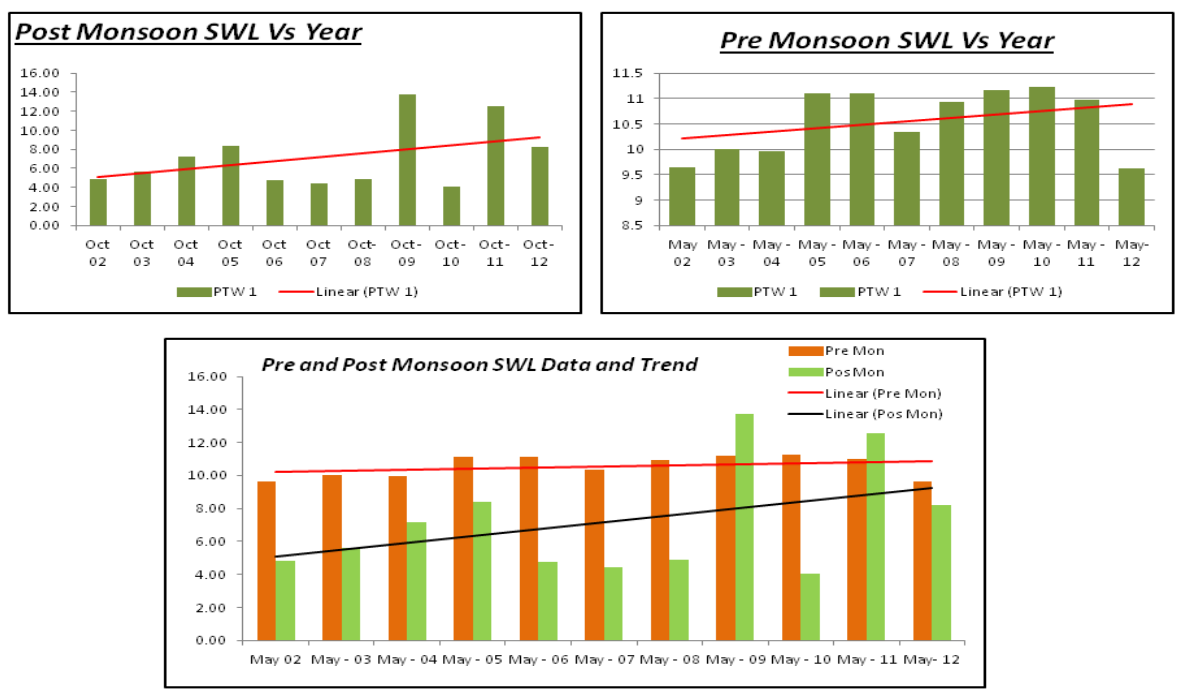

Fig. 5: Decadal trend of Static Water Level analysis in the area. 